\title{
A nők helyzete a magyar tudományos életben
}

\author{
Lannert Judit - Nagy Beáta \\ https://doi.org/10.51624/SzocSzemle.2019.4.3
}

Beérkezés: 2019. 06. 14.

Átdolgozott változat beérkezése: 2019. 11. 05.

Elfogadás: 2019. 12. 23.

\begin{abstract}
Összefoglaló: Bár a magyar felsőoktatás 2012-ig erőteljesen bővült és ezzel együtt nagymértékben feminizálódott, ennek ellenére nem csökkent a diszciplínák közti nagyarányú horizontális nemi szegregáció és nem vált egyszerủbbé a nők előrejutása a tudományos pályán. Ráadásul számos tényező gyengíti a nők jelenlétét és akadályozza a nemi szegregáció csökkenését. Jelen tanulmány a legfrissebb adatok alapján (Felvi, KSH, MTA) bemutatja a horizontális és vertikális szegregáció mintázatait a nők körében a tudományos pályán. A tanulmány az elérhető nemzetközi és hazai szakirodalmak alapján arra keresi a választ, hogy a nők kezdeti létszámbeli előnye a felsőoktatásban miért tủnik el a tudományos pálya magasabb fokain. Ezek alapján azonosítottuk a nemek közötti egyenlőséget akadályozó intézményi és politikai tényezőket a felsőoktatás területén. Mindezek eredményeképpen kialakult egy olyan felsőoktatási politika és gyakorlat, amely megerősíti a nők hátrányait és elnyomja a témával kapcsolatos alternatív diskurzusokat. A tanulmány célja, hogy felhívja a figyelmet arra, hogy a tudományos életben a női tehetségek folyamatos elvesztegetése zajlik, ami egyben a hazai innovációs potenciált is csökkenti.
\end{abstract}

Kulcsszavak: nôk a tudományban, oktatás, nemek egyenlősége, STEM, egyetemi felvételi

\section{Bevezetés}

Magyarországon göröngyösebb a nők útja a tudományos karrier területén, mint a férfiaké. Jellemző, hogy míg a gimnáziumokban és a felsőoktatásban a létszámokat tekintve női fölény tapasztalható, addig a tudományos ranglétrán már elfogynak a nők, és a legmagasabb tudományos szinten, az akadémikusok közt az arányuk mindössze 6\% (MTA 2019). A tanulmány elsősorban arra keres választ, hogy a felsőoktatásban tapasztalható kezdeti női előny miért is tűnik el a tudományos pálya különböző fokozatain.

A tanulmány első része a Felvi, a KSH és az MTA adatbázisainak segítségével azt mutatja be, hogyan alakul a nők aránya az egyetemi képzés kezdetétől az akadémikus pálya csúcsáig a különböző tudományterületeken. A tanulmány második felében arra teszünk kísérletet, hogy a legfrissebb hazai és nemzetközi kutatások alapján választ adjunk arra, vajon mi okozza a nők kezdeti előnyének eltűnését a tudományos pályákon. Különös figyelmet fordítunk az ún. STEM (science, technology, engineering and mathematics) pályákra, amelyek mind nemzetközileg, mind itthon különösen reflektorfényben vannak. Nemzetközileg nagy erőfeszítések történnek azért, hogy

1 A Felvi adatbázis feldolgozásában közremüködött Holb Éva is, akinek segítségét ezúton is köszönjük. 
növekedjen a nők aránya ezeken a technológiai innovációkat segítő területeken. A tanulmány legfontosabb következtetése az, hogy az innovációs potenciál növelése szükségessé tenné, hogy a férfiak és a nők a lehető legjobban kibontakoztassák a tehetségüket az oktatás terén, ami viszont genderszemléletű oktatás- és tudománypolitikát igényelne. Ez azonban kevéssé illik egy, a nemek munkaerőpiaci egyenlőtlenségét elfogadó, férfi kereső-női gondoskodó dichotómiára épülő genderrezsimet megkérdőjelezhetetlennek vevő társadalmi és politikai környezetbe.

\section{Nők a felsőoktatásban és az akadémiai életben}

Több probléma is adódik azon az úton, amíg a lányok eljutnak a nem „lányokra szabott” tudományos pályákig, és ezek egy része már kora kisgyerekkorban megjelenik. A kisgyermekkori szocializációban tetten érhetők az eltérő nemi elvárások és sztereotípiák, amelyek mintegy láthatatlanul terelik a gyerekeket a társadalmilag konvencionális foglalkozások választása felé. Ahogy Pető fogalmaz: „Az első probléma az oktatás és képzés alapszakaszában jelentkezik, mikor a lányokat nem buzdítják arra, hogy foglalkozzanak "fiús« tantárgyakkal, mint a matematika vagy fizika. A »láthatatlan tanterv« pedig a fiúk teljesítményét honorálja, míg a lányokét nem. Ekkor jelentkezik az üvegfal jelensége, amely a nőket bizonyos szakterületekre szorítja, és azokban a szakmákban, amelyek így elnőiesednek, csökkennek a bérek és a szakmával járó presztízs is” (Pető 2018: 553).

$\mathrm{Az}$ iskolarendszerekben nagyobbrészt nők dolgoznak, és az ő reflektálatlan vagy reflektált magatartásuk felerősítheti saját nemük erősségeit vagy gyengeségeit. Széles körű szakirodalom (Wang-Degol 2013; Eccles 1993; Eccles-Roeser 2013; Charles-Thébaud 2018) foglalkozik azzal is, hogy a szülői és pedagógusi percepciók a matematikával kapcsolatban, illetve a matematikához való viszonyuk és a területen elért tudásuk és magabiztosságuk erőteljes befolyást gyakorol gyermekük, tanulójuk matematikai sikerességére (OECD 2019). ${ }^{2}$ A matematikában szorongó pedagógusok tanulói közt a lányok is szorongóvá váltak a matematikában, míg a fiúk esetében ilyen hatást nem találtak. A kutatók ezt azzal magyarázzák, hogy a női pedagógusok nemi szerepmodellt is jelentenek a lányoknak, így annak hatása jóval erősebb az azonos nemú tanulóknál, vagyis a lányoknál (Beilock et al 2009).

Ez a helyzet éppen ezért oda vezet, hogy a nők lényegesen ritkábban választják a már említett STEM-pályákat. Ha mégis elindulnak a sztereotipikusan férfiasnak nevezett foglalkozási karrierúton, igen nagy számban elhagyják a pályát. A nemzetközi szakirodalom a szivárgó vezeték (leaky pipeline) metaforával írja le a női tehetségek elvesztésének a jelenségét (Paksi 2014).

Azok, akiknek mégis sikerül áttörniük az üvegplafont és elérniük a tudományos élet felsőbb szintjeire, általában egy tipikus „férfivilágban” találják magukat,

2 Az OECD PISA 2015 adatbázisa azt mutatja, hogy a magyar szülök elvárása lányaik iránt a STEM területen a legalacsonyabbak közé tartozik, mint ahogy a lányok STEM karrier elképzelései terén is Magyarország a rangsor végén kullog. A kettő minden bizonnyal nem független egymástól. 
ahol nem érzik magukat otthon, és ahol a férfiak által uralt kommunikáció gyakran szorongást vagy negatív érzéseket vált ki belölük (Britton 2017). A fagyos légkör (chilly climate) az egyetemeken még az elnőiesedett humán tudományok területén is megfigyelhető. Ez elriasztja a tehetséges és törekvő nőket, akik így lemondanak a tudományos karrierről, és elesnek attól a lehetőségtől is, hogy példát mutassanak a következő generációk számára (Séllei 2015) - ezáltal is erősítve a nők hátrányos helyzetét a tudományos életben.

\section{A felsőoktatás és a tudományos világ nemi szegregációja}

A világ fejlett országaiban megfigyelhető trendeknek megfelelően Magyarországon is tapasztalható volt, hogy az oktatási expanziók időszakában jelentősen növekedett a női diákok aránya (Fényes 2010). Ez azt jelentette, hogy a 15 éves és idősebb népesség egészét tekintve a rendszerváltozásig a nők átlagos iskolai végzettsége alacsonyabb volt, mint a férfiaké, 1990-től azonban nyilvánvalóvá váltak a generációs cserélődés jelei: előbb a fiatal korosztályokban, majd pedig a népesség egészében magasabb lett a női, mint a férfi diplomások aránya (Varga 2018). A felsőoktatásban tanulók között pedig, még ha a 2004-es csúcspont óta csökkenő tendenciát is látunk, kevéssel 50\% felett állandósult a nők aránya (Varga 2018).

Ez nem jelentette ugyanakkor azt, hogy nagyon magas lenne a felsőoktatási beiskolázási arányszám, de a korábbi időszakhoz ${ }^{3}$ viszonyított növekedés igen jelentős volt: az expanzió első szakasza 1990/91-1996/97 között zajlott, ekkor a felsőoktatásban tanulók számának megduplázódása, majd pedig 2004/2005-re megnégyszereződése zajlott le (Szemerszki-Imre 2011), és elérte az európai átlagot (a korosztály mintegy 40\%-a tanult felsőfokon). Jelentős arányt képviselt a változásban a levelező tagozatban való részvétel, ami aztán a későbbiekben jelentéktelen mértékűre zsugorodott (Varga 2018).

A felsőoktatás feminizálódása ellenére az oktatási rendszeren belül megmaradtak a felsőoktatás szegregációs mintái. Korábban a főiskolák vs. egyetemek dichotómiában lehetett megfigyelni a kiegyenlítetlen női-férfi arányokat, például a közgazdász pálya esetében (Hrubos 1994), a bolognai képzés bevezetése után sokkal inkább a horizontális szegregáció jelenléte a szembetűnő jelenség. Az alap- és mesterképzésben a nők és férfiak aránya tudományáganként szignifikánsan eltérő. A nők körében a legnépszerűbb szakok a közgazdaság-tudomány, a bölcsészettudomány és neveléstudomány. A férfiak körében a műszaki területek, a közgazdaság-tudomány és az informatika. A 2016-os statisztikák szerint a nappali és levelező tagozatos egyetemi hallgatók 51,7\%-a volt nő, a legmagasabb női jelenlét a tanárképzés, oktatástudomány területén (77,3\%), míg a legalacsonyabb a műszaki tudományok $(25,4 \%)$ és informatika (15,1\%) területén figyelhető meg. Az aránytalanságokat jól mutatja, hogy az informatika területét ötször annyi, a műszaki területet pedig há-

3 A szocializmus idejében a felsőoktatásban való továbbtanulás arányát mesterségesen alacsonyan tartották, az adott populáció 10\%-át nem haladta meg ez az arány (Halász-Lannert 2000: 143). 
romszor annyi férfi választja, mint nő. A neveléstudományok területét viszont a nők választják háromszor annyian, mint a férfiak. ${ }^{4}$

Az ISCED-6 kategóriát (felsőfokú tanulmányok) részletesebben elemezve az EFFORTI kutatáson belül Füleki, Groó, Kleinheincz és Paksi (2018) szintén felhívták a figyelmet a műszaki és informatikai területeken a lányok csökkenő arányára. A matematikát tanulók körében a lányok aránya azonban előbb növekedést, majd pedig csökkenést mutatott. Miközben az Európai Unió egészére vonatkozó átlagok egyértelmú trendeket, azaz egyre kiegyensúlyozottabb nemi arányokat jeleznek, addig a magyar adatok sokkal hektikusabbnak tűnnek 2004 és 2012 között.

1. táblázat: A nők arányának alakulása az ISCED6 szinten a természettudományi és mérnöki területeken, 2004, 2010 és 2012 (\%)

\begin{tabular}{|c|c|c|c|c|c|c|c|c|}
\hline & & $\begin{array}{c}\text { Élettudo- } \\
\text { mányok }\end{array}$ & Fizika & $\begin{array}{c}\text { Matema- } \\
\text { tika és } \\
\text { statisztika }\end{array}$ & $\begin{array}{l}\text { Informa- } \\
\text { tika }\end{array}$ & $\begin{array}{c}\text { Múszaki } \\
\text { tudomá- } \\
\text { nyok }\end{array}$ & $\begin{array}{l}\text { Gyártás és } \\
\text { feldolgozás }\end{array}$ & Építészet \\
\hline \multirow{3}{*}{ EU27 } & 2004 & 53 & 34 & 31 & 18 & 19 & 30 & 36 \\
\hline & 2010 & 57 & 34 & 32 & 19 & 23 & 42 & 34 \\
\hline & 2012 & 58 & 37 & 36 & 25 & 25 & 35 & 38 \\
\hline \multirow{3}{*}{$\begin{array}{l}\text { Magyaror- } \\
\text { szág }\end{array}$} & 2004 & 34 & 33 & 40 & 11 & .. & 40 & 33 \\
\hline & 2010 & 56 & 40 & 26 & 14 & 29 & 36 & 53 \\
\hline & 2012 & 49 & 37 & 33 & 6 & 15 & 38 & 18 \\
\hline
\end{tabular}

Forrás: Füleki et al. (2018: 52)

2012-ben üzenetértékű változás zajlott a felsőoktatás állami finanszírozásában. A változásnak két fontos eleme is volt: csökkent az államilag finanszírozott helyek száma, és megjelent a finanszírozásban a tudományterületek közötti különbségtétel. Ez utóbbi azt jelentette, hogy a gazdálkodástudományi, jogi és társadalomtudományi területeken központilag jelentősen felemelték az államilag finanszírozott helyek felvételi ponthatárát, miközben a természettudományi, mérnöki és informatikai pályákon igyekeztek még szélesebbre tárni a bejutási lehetőséget. Ezáltal - a horizontális szegregáció gyakorlatát alapul véve - gyakorlatilag költségtérítésessé tették a jelentős női hallgatói bázissal rendelkező szakokat, míg a korábbiakhoz képest is több finanszírozott helyet biztosítottak a férfi hallgatói bázissal rendelkező szakokon.

A 2012-es költségvetési megvonások hatására - nem meglepő módon - a közgazdaság-tudományi és jogtudományi képzések terén visszaesés következett be mind a nők, mind a férfiak létszámában, de a nők esetében a visszaesés nagyobb arányú volt (lásd 1. ábra). A felsőoktatásba jelentkezőket és felvetteket is tartalmazó felsőoktatási statisztikai adatbázis alapján ${ }^{5}$ azt mondhatjuk, hogy a közgazdaság-tudo-

4 A magyar felsőoktatás tudományági nemi mintázata hasonló az európai országokéhoz, ugyanakkor figyelemre méltó, hogy arányaiban szélsőségesebb. Míg európai átlagban a férfihallgatók egyötöde tanul műszaki területeken, addig Magyarországon $30 \%$ ez az arány. A neveléstudomány terén pedig az európai átlag a nők körében $10 \%$, Magyarországon viszont majdnem az egyötöde a nőknek (17\%) ezt a területet célozta meg. Feltűnő még, hogy a természettudományok terén kirívóan alacsony a hallgatók aránya Magyarországon, akár nőről, akár férfiról van szó (3-4\% az európai 7-9\%-hoz képest) (Eurostat, 2016).

5 FIR OSAP-adatbázis, elérhető az Oktatási Hivatal honlapján: https://www.oktatas.hu/felsooktatas/kozerdeku_adatok/ felsooktatasi_adatok_kozzetetele/felsooktatasi_statisztikak. 
mányok terén a nők esetében a 2012-es csúcs után 2017-re a kétharmadára, a férfiak esetében viszont csak a 78 százalékára csökkent a létszám. A jogtudományok terén a nők száma a 2012-es csúcs 64 százalékára, a férfiak esetében csak a 74 százalékára esett vissza 2017-re. Az informatika terén a nők esetében az adott időszakban 10 százalékos javulás tapasztalható (de eleve alacsony létszámokról van szó, 2361 főről 2602 főre változott a létszám), a férfiak esetében pedig 10 százalékos a csökkenés (16 296 főről 14778 főre). A műszaki területeken a nők száma 10 százalékkal, a férfiaké pedig 15 százalékkal csökkent. Összességében ezen a négy, a munkaerőpiacon jól megfizetett területen (közgazdaság, jog, műszaki pályák, informatika) a nők vesztesége nagyobb, az ő létszámuk 30 százalékkal csökkent, míg a férfiaké csak 20 százalékkal. A költségvetési megvonások ráadásul eredeti céljukat nem érték el, az informatikai és műszaki képzésben sem következett be a várt növekedés.

1. ábra: A nők és férfiak részvétele a BA- és MA-képzéseken tudományáganként 2008-2017, (fö)

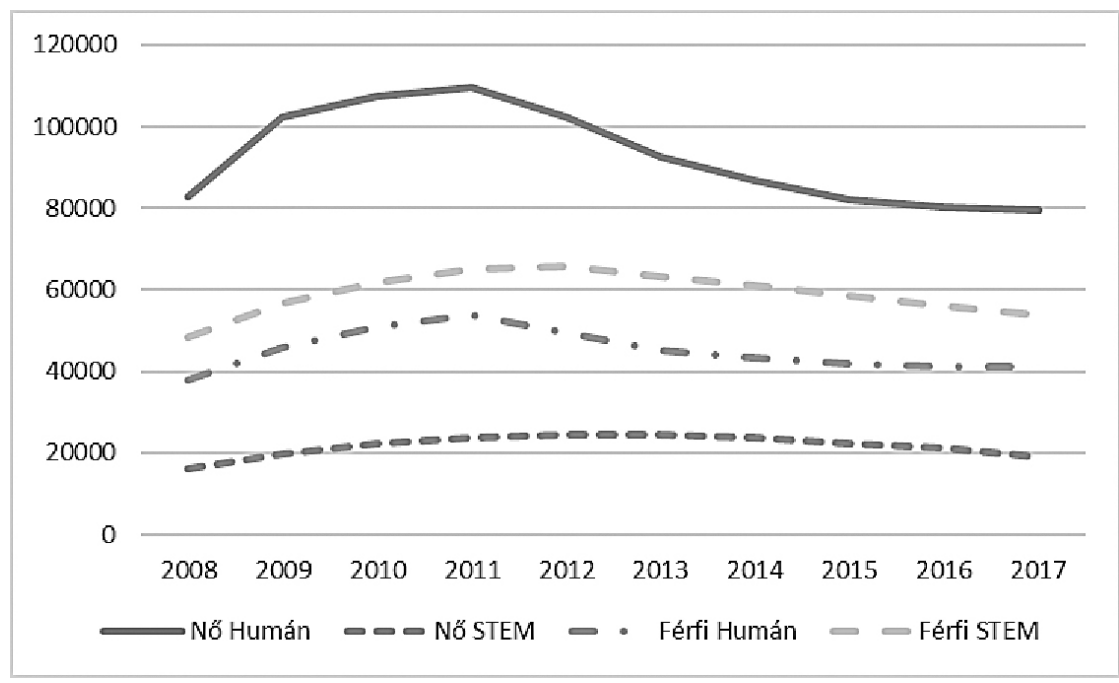

Megjegyzés: STEM: természettudomány, matematika, műszaki tudományok, informatika. Humán: bölcsészet, múvészet és társadalomtudományok.

Forrás: Felvi statisztika, saját számítás

\section{Lemorzsolódás a nők körében fokozatonként és tudomány- területenként}

A felsőoktatási statisztika (FIR) alapján elmondható, hogy 2008 és 2017 között folyamatosan nagyobb a nők részvétele a felsőfokú oktatás alap- és mesterszintjein 
(53\% 2017-ben), mint a férfiaké, ugyanakkor a doktori képzésen az arányuk alacsonyabb (47\% 2017-ben), és az utóbbi néhány évben ráadásul csökkenő tendenciát mutat. Érdemes területenként is megfigyelni, hogy az alap- és mesterfokozat után milyen arányban mennek doktori képzésre a nők az adott tudományágakban, és ott milyen arányban szerzik meg a doktori fokozatot. Háromféle dinamikát különböztethetünk meg a nemek helyzetét vizsgálva. Az egyik, ahol egy adott területen eleve nagyobb arányú a nők részvétele, és ez az előny nem tűnik el, vagy legfeljebb csak kevéssé a doktori fokozatot elérve. Ilyennek tekinthető a neveléstudomány és az egészségügy (bár ez utóbbi esetében a fokozatszerzés terén már eltűnik a nők előnye).

2. ábra: $A$ hallgatók létszáma a neveléstudomány és egészségtudomány terén $B A, M A$, doktori szinten és a fokozatot szerzők száma nemenként, 2008-2017 (fö)
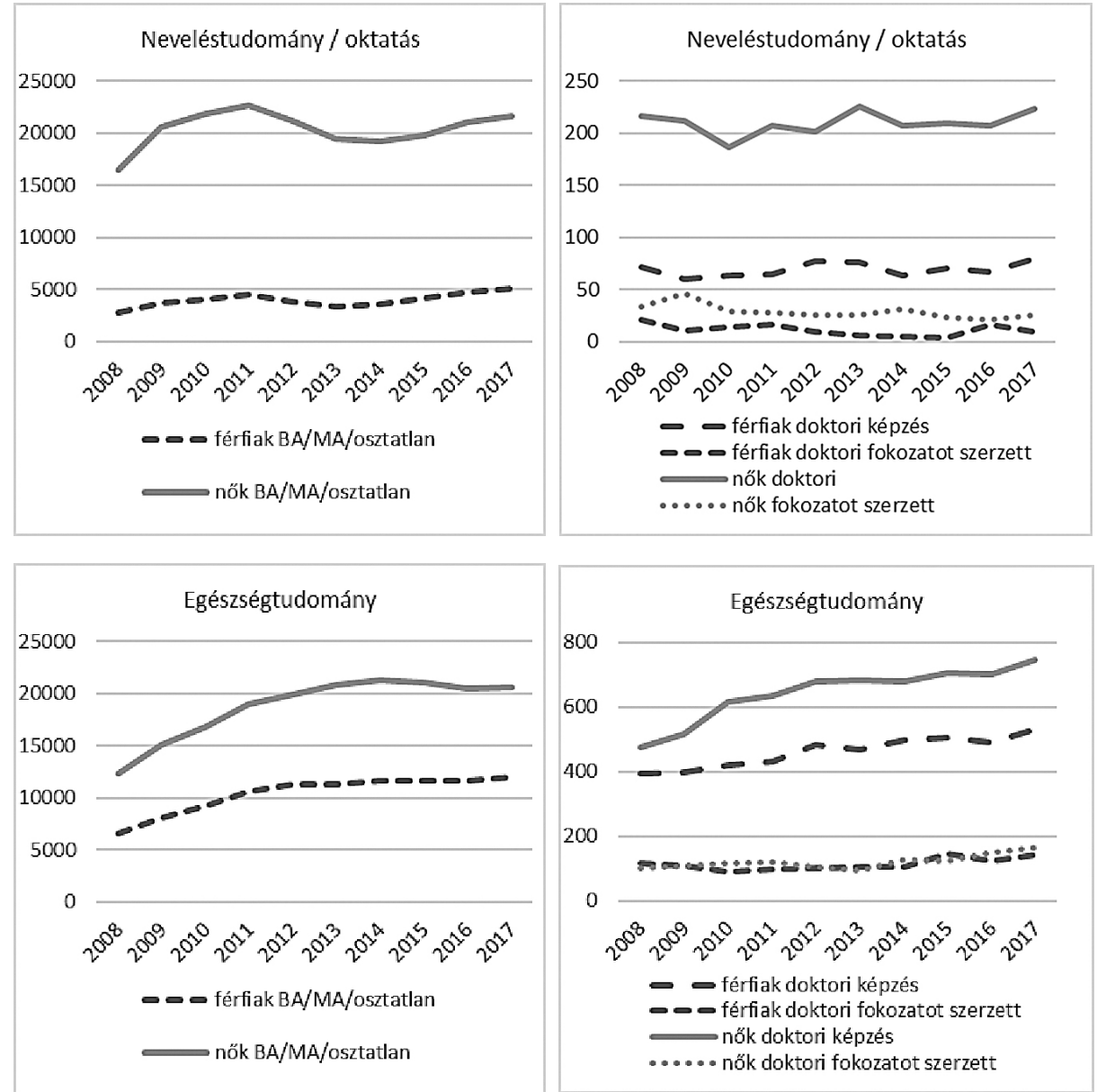

Forrás: Felsőoktatási statisztika, saját számítás 
A másik típus, ahol a nők kezdeti előnye a doktori képzéshez, majd a fokozatszerzéshez érve eltűnik. Ilyen a közgazdaság-, illetve a gazdálkodástudomány és a jog területe.

3. ábra: A hallgatók létszáma a közgazdaság és gazdálkodástudomány, valamint az államés jogtudomány terén BA, MA, doktori szinten és a fokozatot szerzők száma nemenként, 2008-2017 (fö)
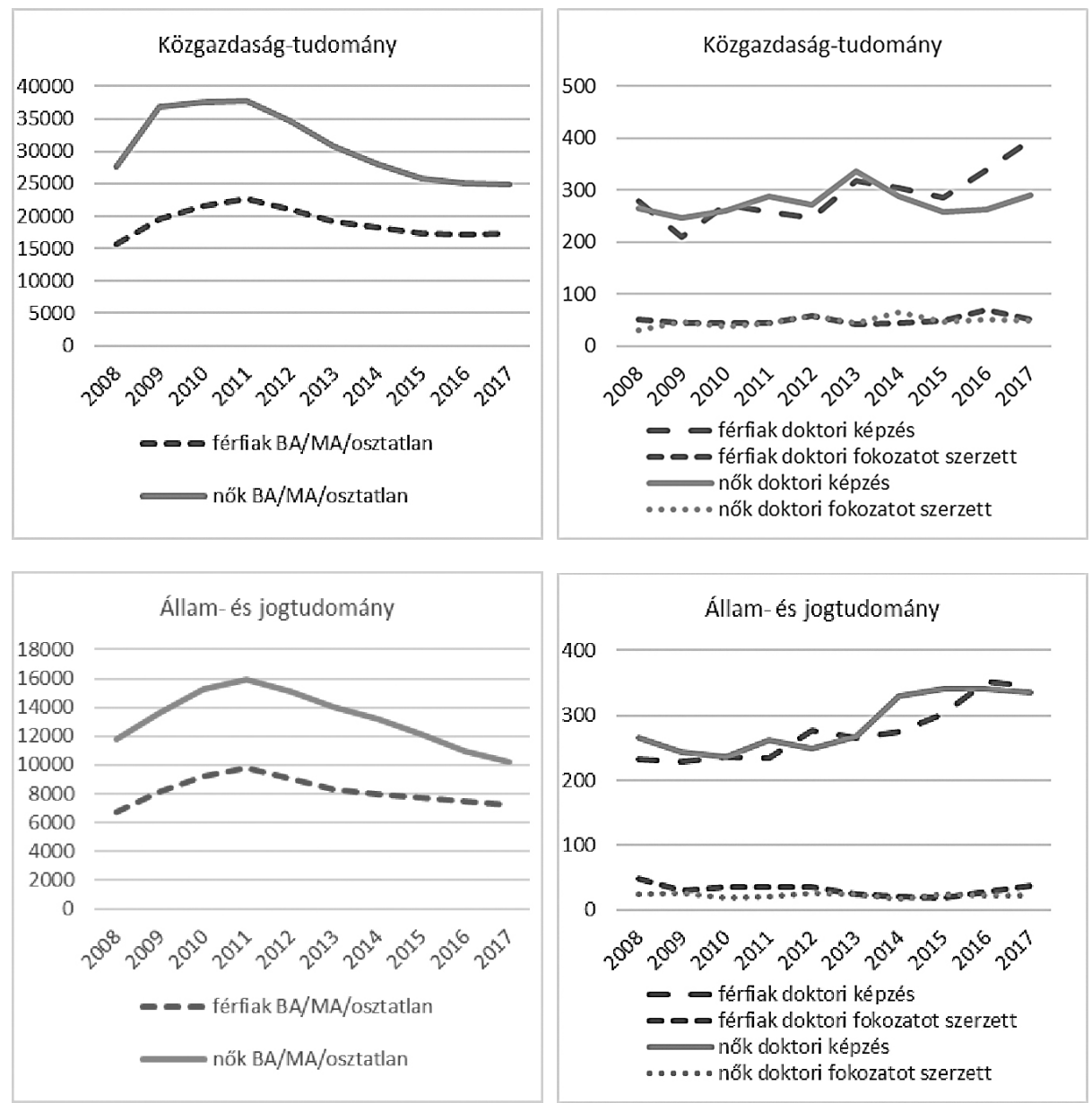

Forrás: Felsőoktatási statisztika, saját számítás

A harmadik típusú képzések azok, ahol a nők kisebb arányban vesznek részt a képzés mindegyik fokán, és ez a tendencia semmilyen változást nem mutat. Ilyenek a múszaki területek és az informatika. 
4. ábra: $A$ hallgatók létszáma a müszaki tudományok és informatika terén $B A, M A$, doktori szinten és a fokozatot szerzők száma nemenként, 2008-2017 (fő)
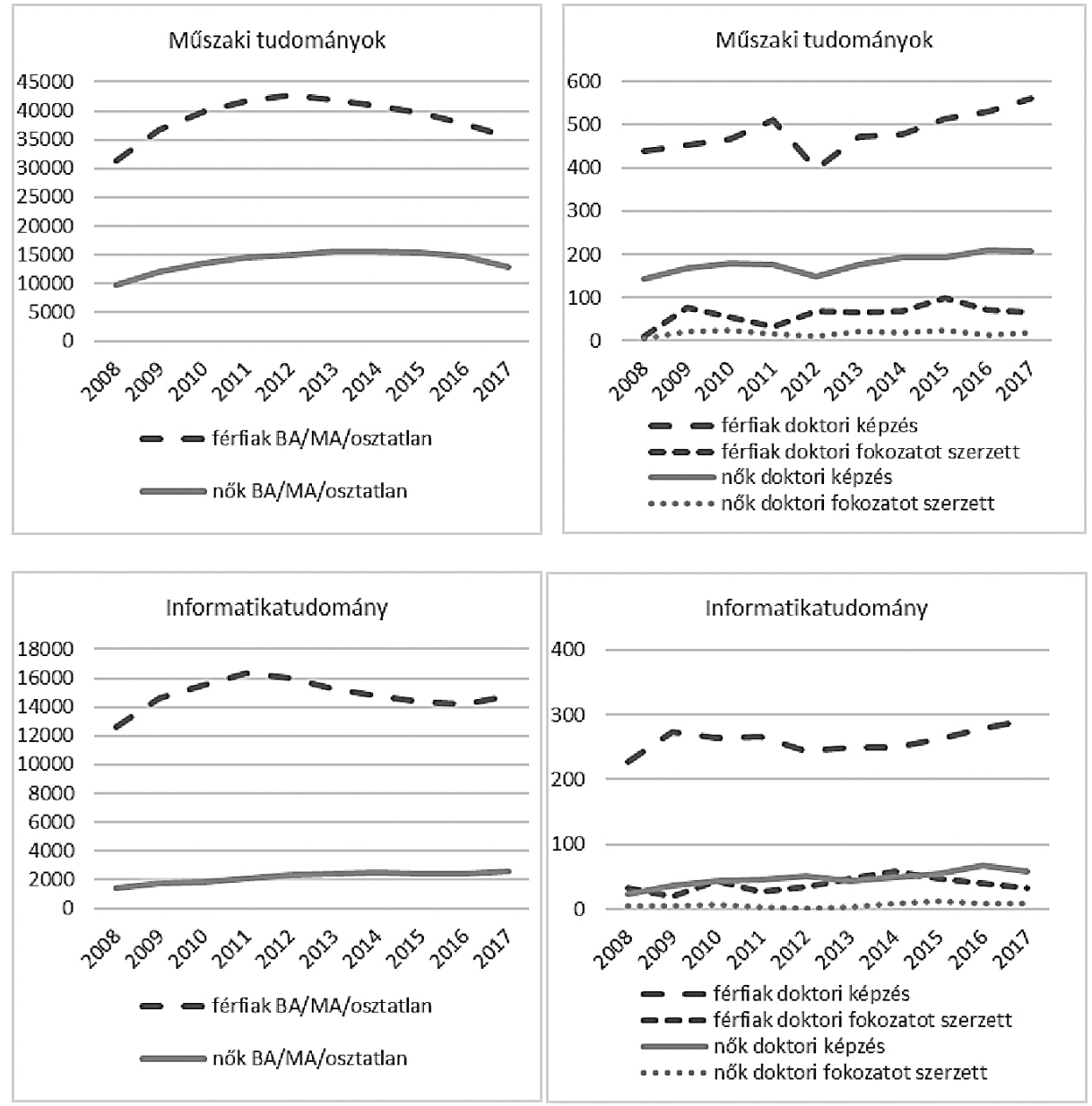

Forrás: Felsőoktatási statisztika, saját számítás

Sajátos terület a természettudomány, ahol a férfiak és nők egyenlő arányban vesznek részt az alap- és mesterképzésben, viszont a doktori képzésen már a férfiak vannak többségben. A fokozatszerzést tekintve a két nem közt alig van különbség. A természettudományok tehát eltérően müködnek az informatikai és műszaki képzéshez viszonyítva. Azt mondhatjuk, hogy a STEM terén a kevésbé kompetitív és elméleti beállítódású természettudomány és matematika terén nincs nemek közötti különbség. E jelenséget részben az magyarázhatja, hogy nemzetközi viszonylatban is kirívóan alacsony a férfiak és nők száma ezen a területen Magyarországon. Viszont a kompetitívebb szakokon, mint a mérnöki és informatikai, a lányok hátránya tetemes. Érdemes itt felhívni a figyelmet arra is, hogy a hazai $\mathrm{K}+\mathrm{F}$ források föleg ez utóbbi területekre és elsősorban a vállalati szektorba folynak, ami tovább fokozza a nők lemaradását a tudományos területen. 
5.ábra: A hallgatók létszáma a természettudományok terén $B A, M A$, doktori szinten és a fokozatot szerzők száma nemenként, 2008-2017 (fö)
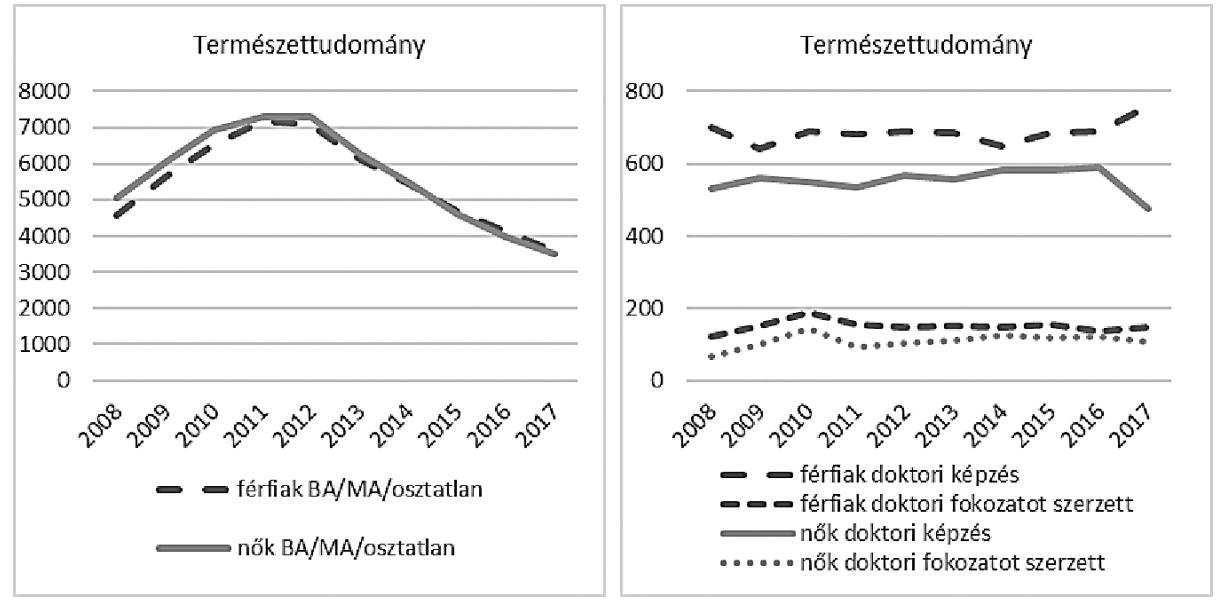

Forrás: Felsőoktatási statisztika, saját számítás

\section{Aránytalanságok az akadémiai szektorban és a kutatásban}

A tudományos pálya egészét tekintve annak ellenére, hogy a mesterképzésben még a nők vannak jelen nagyobb arányban, a tudományos ranglétra magasabb egyetemi és akadémiai fokozatain már megfogyatkozik a nők száma/aránya. Az egyetemi előrejutás nemi mintázata azt mutatja, hogy a PhD-fokozat megszerzése után a felsőoktatásban folyamatosan egyre nagyobb arányt tesznek ki a férfi tudósok, és így kialakulhat a nőket hátrányosan érintő, a fentiekben említett rideg szervezeti kultúra. Ha a tudományos fokozatok megszerzését vizsgáljuk (a mesterszakos diploma megszerzésétől az akadémikussá választásig), akkor a nők kezdeti előnyéinek szertefoszlását láthatjuk. 
6. ábra: Nők és férfiak aránya a tudományos élet egyes pontjain, 2019 (\%),

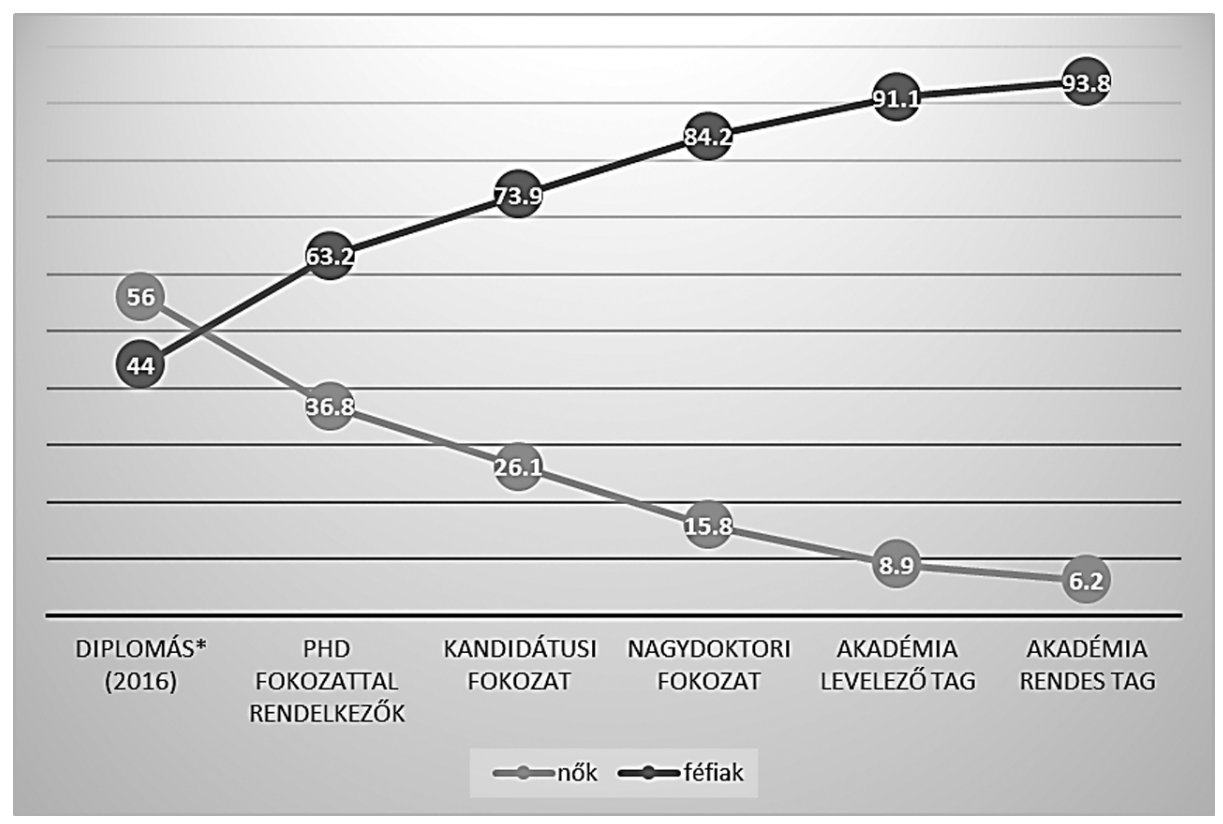

Megjegyzés: diplomások aránya 2016 census adat, KSH

Forrás: MTA (2019)

A Magyar Tudományos Akadémia rendes tagjai között a nők aránya átlagosan 6,2\% volt, és egyik tudományterületen sem haladta meg a 15\%-ot 2019 áprilisában, az utolsó akadémikusválasztás előtt. Miként a legfrissebb adatok mutatják, a legmagasabb a női akadémikusok aránya az MTA II. osztályában (Filozófiai és Történettudományok) és V. osztályában (Orvosi Tudományok), míg a legalacsonyabb a matematikai és műszaki osztályokban ( $3 \%$ alatt). 


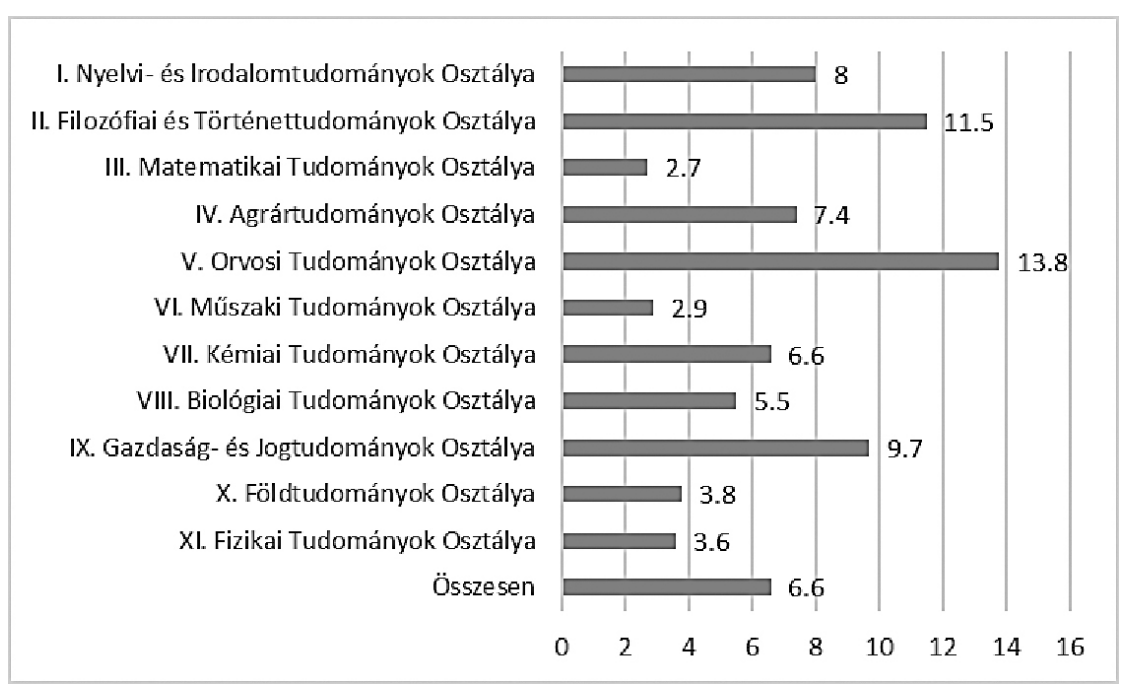

Forrás: MTA (2019)

A $\mathrm{K}+\mathrm{F}$ szektorban is aránytalanságok tapasztalhatók a nők és férfiak részvételében (Striebing et al. 2020). Magyarország nemzetközi összehasonlításban nem költ sokat a $\mathrm{K}+\mathrm{F}$ területre. A kutatásra fordított kiadások háromnegyede a vállalati szférában költődik el, ahol jellemzően alacsony a női kutatók aránya. 2017-ben nemzetgazdasági szinten a bruttó hazai termék (GDP) 1,35\%-át fordították - több mint 517 milliárd forintot - kutatás-fejlesztésre Magyarországon (KSH 2018). Ennek az összegnek több mint a fele vállalati, harmada költségvetési, és a maradék 16\% külföldi és nonprofit forrásokból adódik össze. A K+F kiadások háromnegyede vállalati kutatóhelyeken kerül elköltésre, 13-13\% pedig a felsőoktatási, illetve államháztartási kutatóhelyeken. Az állam egyenlő arányban finanszírozza a különböző fenntartású kutatóhelyeket. A nők és férfiak aránya ugyanakkor meglehetősen nagy aránytalanságokat mutat. 2017-ben 60932 főt alkalmaztak a különböző kutatóhelyeken, akiknek 70\%-a volt kutató, 18\%-a segédszemélyzet és $12 \%$-a egyéb fizikai munkakörben dolgozott. A vállalati kutatóhelyeken dolgozik ennek a populációnak majdnem a fele, $36 \%$ a felsőoktatásban és $15 \%$ az államháztartási szektorban. A kutatóhelyeken dolgozók 37\%-a nő, de arányuk kirívóan alacsony a vállalati kutatóhelyeken (25\%), míg a felsőoktatásban és az államháztartási kutatóhelyeken arányuk megközelíti az 50 százalékot. Ugyanakkor beosztásuk szerint mindegyik területre jellemző, hogy a kutatók közt jóval kisebb a nők aránya, míg a segédszemélyzet és a fizikai dolgozók közt jóval nagyobb. Míg az államháztartási kutatóhelyeken a női kutatók száma a férfi kutatók háromnegyedét teszi ki, a felsőoktatásban a kétharmadát, ugyanakkor a vállalatoknál csak az egyötödét! A felsőoktatási és államháztartási kutatóhelyekre viszont az jellemző, hogy másfélszer-kétszer annyi nő dolgozik fizikai munkakörben vagy segédszemélyzetként, mint férfi (KSH 2018). 
8. ábra: Nők és férfiak részvétele a K+F szektorban beosztás és terület szerint, 2017 (fö)

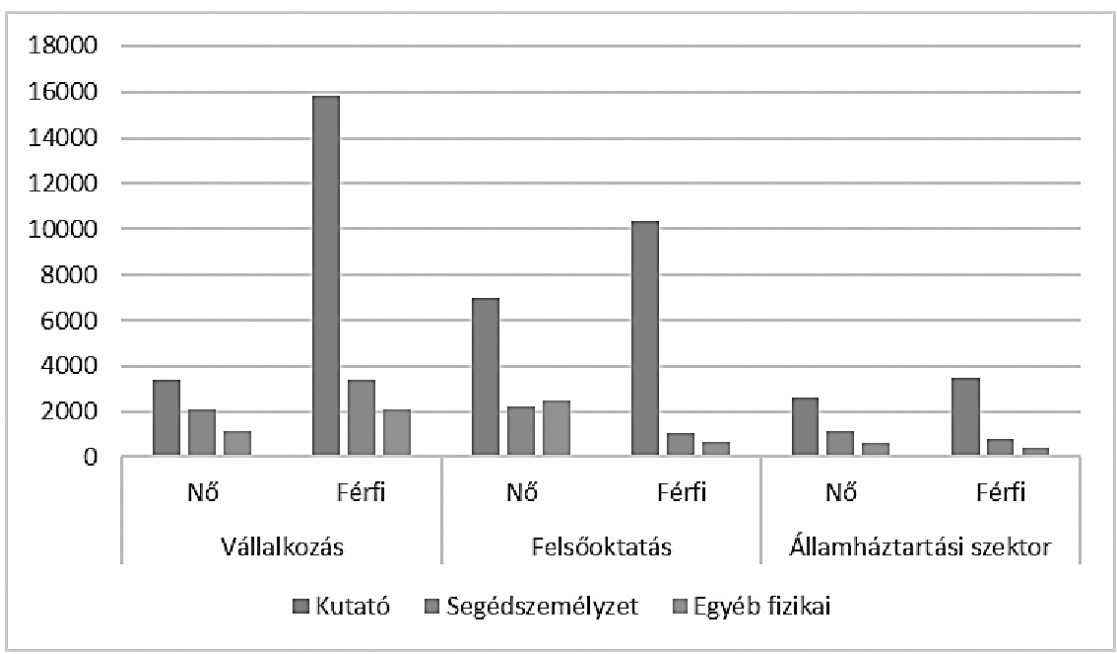

Forrás: KSH (2018)

\section{Nók és a barátságtalan akadémiai légkör}

A nők számára barátságtalan vagy nem támogató akadémiai környezet ott is jelen lehet, ahol a nők a végzős vagy doktori hallgatók többségét képviselik. A szociológia viszonylag szúk tudományos területeit tekintve több akadályt is feltártak az elmúlt három évben végzett interjúk alapján: a gyerekszülés okozta kiesés, a munka és a magánélet közötti egyensúlytalanság, a korlátozott nemzetközi kutatói karrier, továbbá a tudományos láthatóság hiánya (Herke et al 2019). Ez utóbbi azt jelenti, hogy a nők nem kapnak akadálymentes hozzáférést a kutatási lehetőségekhez és figyelmet akadémiai közösségük és vezető munkatársaik részéről.

A Budapesti Corvinus Egyetemen félig strukturált életútinterjút készítettek 9 férfival és 7 nővel, hogy feltárják a doktori iskolában végzettek tipikus pályafutását. Az interjúk a Budapesti Corvinus Egyetem Szociológiai Doktori Iskolájában végzettekkel készültek, továbbá olyan kutatókkal is, akik itt kezdték meg tudományos pályafutásukat. A magyar tudományos szférában dolgozó női interjúalanyok még a rugalmas munkakörülmények közepette is a különféle területek összekapcsolásának nehézségeiről beszéltek (Herke et al 2019). A válaszadók többsége nehezményezte, hogy egyszerre kellene jól teljesíteniük a kutatásban, az oktatásban és az egyetemi adminisztratív és vezetői feladatokban. A nők hangsúlyozták a családi élet prioritását is. Esetükben a gyermeknevelés dominánsan rájuk háruló felelőssége fokozta az időnyomást és az állandó stresszhelyzetet. Az interjúkból továbbá az a kép tárul elénk, hogy inkább a férfiak, mint a nők célja állandóan jelen lenni a tudományos tevékenységekben, egyszersmind nemzetközi elismerést is szerezni. Az interjúalanyok közt csak a 
férfiak esetében fordult elő, hogy kutatói karrierjük során hosszabb időre is eljutottak nemzetközi kutatóhelyekre (Herke et al. 2019).

Nemrégiben készült egy másik tanulmány a fiatal (45 év alatti) kutatók körében. ${ }^{6}$ Az eredmények szerint a válaszadók 13,7\%-a jelezte, hogy tudományos karrierje során neme, nemi, kisebbségi identitása vagy fogyatékossága miatt hátrányos megkülönböztetésben részesült. Míg a nők 27,9\%-a (az akadémiai szektorban 21,7\%), a férfiak csupán 4,1\%-a válaszolt igennel erre a kérdésre (Alpár et al. 2019: 1075). További fontos szempont, hogy a női válaszadók a férfi kutatókhoz képest gyakrabban számoltak be az elismerés hiányáról és a túlterheltségről, melyek kutatói karrierjük demotiváló tényezői. Jellemző módon a 31 és 40 évesek közt a férfiak felülreprezentáltak a vezetők, a 31 és 35 évesek közt pedig a docensek körében. Megjegyzendő, hogy a tudományos pozíciókat tekintve a nemek közötti szakadék a tudományos előmenetelben már 45 éves kor előtt megnyílik (Alpár et al. 2019). A nemzetközi kutatási tapasztalat fontos az akadémiai karrier minden szakaszában, ezért meglepő, hogy a válaszadók 59,7\%-a nem volt külföldön három hónapnál hosszabb ideig a diploma megszerzését követően, és ez az arány a nők esetében jóval magasabb (67,5\%), mint a férfiak esetében (54,4\%). Ez abból is fakad, hogy a nők sokkal nehezebben tudják összeegyeztetni a családi feladatokat a munkával (Paksi-Nagy-Király 2016). A női kutatók ezért nagyon gyakran későn, vagy nem alapítanak családot. A kisgyermeket nevelő nők 45\%-a jelezte, hogy családi helyzete miatt hátrányos bánásmódban részesült az akadémiai életben. Ez még inkább jellemző a mérnöki, az orvostudomány és a kémiai tudományok területén, ahol kevés a fiatal, hadra fogható kutató.

\section{A háttérben lévő okok - a genderszemlélet hiánya az oktatás- és tudománypolitikában}

A fiúk és lányok közötti különbségekre a PISA-vizsgálatok is felhívják a figyelmet. Világszerte jellemző tendencia, hogy a szövegértés területén a lányok, a matematika területén a fiúk teljesítenek jobban. A 2015-ös európai kompetenciamérési adatok elemzése során a kutatók arra a következtetésre jutottak, hogy nem annyira a nemek közötti különbségek nagyságában vannak az eltérések, hanem inkább bizonyos iskolarendszerekben. Finnországban a lányok, más országokban pedig (pl. Ausztria) a fiúk teljesítenek relatíve jobban mindhárom területen. A különbségek mögött tehát feltételezhetően tanítási módszerek és iskolaszerkezeti különbségek húzódhatnak meg. Az adatok azt is mutatják, hogy a diákorientált tanítási gyakorlat kedvező hatással lehet a lányok teljesítményére (Hermann 2018; Hermann-Kopasz 2018).

Magyarországon a PISA-tesztpontszámok nemek közötti különbsége átlagosnak mondható. Matematikából a fiúk valamennyivel jobbak, a szövegértés terén viszont

6 Az online kérdőívet 2018. március 12. és április 9. között töltötte ki a Magyar Tudományos Akadémia 45 éves kor alatti 1779 tagja. A minta nem volt reprezentatív, és a kutatók az elemzés során kiszúrték a 45 év felettieket (18fö), azokat, akik külföldön dolgoznak (39 fö), a doktoranduszokat (52fö), valamint azokat, akik nem határozták meg a munkahelyüket vagy pozíciójukat (135 fö), tehát a statisztikai elemzés összesen 1535 választ vizsgált. 
a lányok előnye az európai átlagnál kisebbnek mondható. A természettudományok terén nincs szignifikáns különbség. Egy, a magyar tanulók matematikai teljesítményében bekövetkezett romlás mögötti okokat kereső magyar tanulmány összehasonlította öt közép-európai ország (Németország, Lengyelország, Csehország, Szlovákia és Magyarország) tanulóinak teljesítményét a PISA 2012-es adatbázisán (Csüllög-D. Molnár-Lannert 2014). A matematikai teljesítményre ható tényezőket többváltozós regressziós elemzésnek vetették alá. Ez alapján a családi háttér és a nem a teljesítményekben meglévő variancia egyötödét magyarázta. További egyötödöt magyarázott viszont a tanulók matematikai énképe és önhatékonysága, vagyis az, hogy mennyire magabiztosak ezen a területen, mennyire tudják elképzelni, hogy meg tudnak birkózni a matematikai feladatokkal. Érdekes eredménye az elemzésnek, hogy a motiváció kontrollálásával a nem és a matematikai teljesítmény közötti összefüggés negatívról pozitívra változik. Vagyis ugyanolyan motivációs szinten a lányok már jobban teljesítenek matematikából, mint a fiúk.

A tanárképzés elméleti hátterének vizsgálatakor szembetűnő a kutatásokra alapozott elméletalkotás helyett a tradicionális, történeti narratíván alapuló tudományos alapozás, ami ezzel újratermeli az univerzalizáló, egyöntetű emberképet mint nevelési ideált (Thun 2006). A nők láthatatlansága, mint a rejtett tanterv része hatással van az osztálytermi és társadalmi erőviszonyokra, erősíthet, újraformálhat vagy akár transzformálhat (Thun 2006; Nagy 2014). A gender szemléletmód hiánya jellemezte az Országos Közoktatási Intézet által rendszeresen kiadott, a magyar közoktatásról szóló jelentéseket is, amelyek a puszta statisztikák mögötti tendenciákat figyelmen kívül hagyva nem érzékeltek problémákat a nemi egyenlőség terén (Kereszty 2007). Pedig a genderszemlélet érvényesítése a közoktatásban hozzájárulhatna ahhoz, hogy a lányokat hatékonyabban tudják terelni a hazai technológiai innováció számára oly fontos tudományterületekre. ${ }^{7}$

A felsőoktatás-politikában is kimutatható, hogy a gendervakság vagy genderellenesség, lásd a társadalmi nemek mesterszak megszüntetését, célellentétes következményekkel jár. A középiskolások továbbtanulási döntéseit nyilvánvalóan erősen befolyásolhatja a felsőoktatási rendszer változása. Ahogy erről az előzőekben már szó volt, a felsőoktatás expanziójával nőtt a női jelenlét a felsőoktatásban, majd a 2006-os csúcspont után csökkent. Ezt a csökkenési folyamatot megerősítette a felsőoktatási férőhelyek finanszírozásának 2012. évi átalakítása.

Bár a közvetlen cél az ún. STEM-szakterület támogatása volt, közvetett módon hátrányos helyzetbe hozták a nem STEM-területen továbbtanulni szándékozó fiatalokat. Friss, a felsőoktatási jelentkezéseket vizsgáló elemzések rámutatnak arra, hogy bár a jelentkezések száma összességében is csökkent, a lányok esetében különösen jellemző ez a változás: a 2011-es 61,8\%-ról a 2012-es 54,8\%-ra zuhant a felsőoktatásba jelentkező női hallgatók aránya az adott évben érettségizettekhez képest.

7 Például annak tudatosulása, hogy az alsós tanítónők korrekt természettudományos képe és lányokat motiváló pedagógiai eszköztárral való felvértezése alapvető fontosságú, az egyik kulcsa lehet egy sikerre áhító innovációs politikának. 
A férfiaknál ez a csökkenés 54,4\%-ról 49,8\%-ra változott (Declercq-Varga 2018). Ahogy a kutatók megállapították: „A férfiak tehát inkább a STEM-jelentkezéseik növelésével válaszoltak a 2012. évi változásokra, míg a nők nagyobb valószínűséggel jelentkeztek költségtérítéses képzésre 2012 után” (Declercq-Varga 2018: 116). Ez azt jelenti, hogy visszaesett a nők aránya az államilag finanszírozott képzésben: 1,9\%-ról 10,2\%-ra nőtt az első helyen költségtérítéses képzésre jelentkező lányok aránya. A férfiaknál ugyanez a jelentkezési arány 1,7\%-ról 6,7\%-ra nőtt.

\section{Következtetések}

Tanulmányunk arra kívánt rámutatni, hogy a közvélekedéssel szemben, miszerint az oktatási rendszer feminizálódása a nőknek kedvez, a nőkre váró tudományos pályán valójában számos rejtett és nyílt akadállyal kell megküzdeniük, hogy ugyanolyan eredményesek legyenek, mint férfi társaik. Ezek az akadályok rendszerszerúen veszik körbe a társadalom női tagjait az életútjuk során, és ezért kora kisgyermekkortól kezdődően megerősítik a nők és férfiak teljesítményével kapcsolatban elvileg meritokratikus és egyenlő, gyakorlatilag mélyen hagyományos és diszkriminatív elvárásrendszert.

Ahogy a tanulmányunkban is írtuk, a közoktatásban aktívan tetten érhető a rejtett tanterv múködése, azaz azok az utalások, amelyek kijelölik a nemek helyét a társadalmi valóságban. Ezzel a nemekre lebontott, rutinszerűen reprodukált és továbbadott hagyományos világképpel az oktatási rendszer megerősíti a lányok és fiúk hagyományos szerepét, egyszersmind befolyásolja a saját magukról kialakított önképet is. Különösen így van ez, ha a pedagógusképzés és neveléstudomány, még ha nagymértékben nők által dominált is, nem reflektál a társadalmi változásokra. Ennek a jelei tetten érhetők voltak például akkor, amikor a PISA-vizsgálatban a matematikai eredményekben meglévő nemek közötti különbség eltűnt a matematikával kapcsolatos motivációk modellbe való bevonásával. Ez azt jelenti, hogy a 15 éves lányok nem kevésbé tehetségesek matematikából, mint a fiúk, ugyanakkor saját önképükben és motivációjukban ritkán jelenik meg a matematika iránti lelkesedés és a matematikával összefüggő későbbi pályaválasztás. Ez pedig megmagyarázhatja, hogy miért érdeklődnek elenyésző arányban a nők az ún. STEM-pályák, különösen annak mérnöki és informatikai területe iránt.

A fiúk és lányok tudományos szegregáltsága nem csökken a felsőoktatásba lépve sem. A hallgatói létszám feminizáltsága Magyarországon is megfigyelhető, de a 2006-os időszakot követően és a levelező képzés arányának csökkenésével egy időben viszonylag kiegyensúlyozott, 53\% körüli szintre állt be. Nem kedvezett a női továbbtanulásnak a 2012-es oktatáspolitikai változás sem, amely során az államilag finanszírozott helyekhez való hozzájutás csökkent azokon a tudományterületeken, amelyeket a lányok gyakrabban választanak. Éppen ezért - bár mindkét nem esetében csökkent az érettségizők között a felsőoktatásba jelentkezők aránya - ez a csök- 
kenés lényegesen nagyobb volt a nők, mint a férfiak esetében. A 2012-es év tehát mindenképpen törésnek tekinthető a nők számára a tudományos területekre való belépés növekvő korlátozottsága miatt - pedig a nők számára különösen fontos a továbbtanulás, hiszen a középfokú szakképzés alig kínál számukra szakmákat.

Eredményeink azt mutatták, hogy még ha kicsit magasabb is a női egyetemi hallgatók száma, mint a férfiaké, egyrészt jellemző a diszciplínák szerinti szegregáció fennmaradása, másrészt a tudományos pályán való elindulás kevésbé nyilvánvaló alternatíva a nők számára. A tudományos fokozatok és beosztások vizsgálata egyaránt azt mutatja, hogy az egymás után következő fokozatokat vagy beosztásokat egyre kevesebb nő szerzi meg. Ennek következtében a tudományos hierarchia, például a doktori fokozattal rendelkezők csoportja, még azokon a területeken is férfiarcú lesz (jog, gazdálkodástudomány), ahol pedig az egyetemi hallgatók körében egyértelmű volt a nőtöbbség.

Nem véletlen tehát, hogy a nők Magyarországon kiszorulnak a kutatás-fejlesztés világából. A K+F támogatások, amelyek elmaradnak az európai uniós méretektől a GDP arányában, nemcsak hogy azokra a tudományterületekre áramlanak nagyobb arányban, amelyeken inkább dolgoznak férfi, mint női kutatók (ld. műszaki terület), hanem az elmúlt évek tendenciái azt bizonyítják, hogy ezek a források elsősorban az üzleti szféra tevékenységét támogatják. Ezzel szemben a női kutatók lényegesen gyakrabban dolgoznak a felsőoktatásban vagy az állami szférában, amelyek, bár kevesebb keresetet biztosítanak számukra, mégis jobban lehetővé teszik a munkamagánélet egyensúly kialakítását, mint a versenyszféra munkafeltételei. Ez nem azt támasztja alá ugyanakkor, hogy a nők kevésbé lennének képesek a versenyben való helytállásra, sokkal inkább a genderrezsim hagyományos elvárásai szerint elsődlegesen az ő feladatuk a társadalmi reprodukcióval kapcsolatos feladatok elvégzése.

Nemcsak a neveléstudomány és oktatáskutatás terén, de a felsőoktatás- és a tudománypolitika müködése során is a genderérzékenység teljes hiányát, az ún. gendervakságot figyelhetjük meg (gender blind szemlélet). Ennek magyarázó tényezői, hogy országos szinten hiányzik a nők helyzetére való speciális odafigyelés, a nemek egyenlőségével foglalkozó esélyegyenlőségi politika számonkérése. Magyar specialitásnak tekinthető, hogy 2010 után először a probléma szőnyeg alá seprésével, negligálásával, majd legitimitásának támadásával erőteljes visszarendeződés indult el ezen a téren. Nem pusztán gendervakságról, de genderellenes vagy antigender mozgalomról is van szó a tudományban (Pető 2017).

Ez a folyamat illeszkedik az esélyegyenlőségi politikák kiüresedésébe, amelyet már a 2000-es évek végén leírtak a kutatók (Krizsán-Zentai 2006). Ugyanakkor 2010-től a közpolitikában a nemek helyzetére vonatkozó esélyegyenlőségi politikák érvényesítése és ellenőrzése helyett a családpolitikai intézkedések lettek hangsúlyosak. Így az egyetemista hallgatók gyermekvállalásra ösztönzése fogalmazódott meg a kormányzati politikában, például a diplomás gyed formájában. Ez utóbbi azt jelenti, hogy 2014-től a nappali tagozatos hallgatóknál „a felsőfokú tanulmányok 
folytatása alatt vagy azok befejezését követő egy éven belül szülő kismamának is jár a gyed" (Infojegyzet 2014: 3). Ugyancsak figyelmen kívül maradt a 2010. évi nemzeti stratégia a nemek közötti egyenlőség megvalósítására (Kormányhatározat, 2010), és általában is elmondható a nemi egyenlőségre vonatkozó intézményrendszer hiánya. A nemek egyenlőségére vonatkozó nemzeti stratégiát, amely teljes egészében igazodott az EU 2006-2010 között érvényben lévő Gender Roadmapjához, a mai napig nem léptették hatályba.

Eredményeink nem támasztják alá tehát azokat a várakozásokat, amelyek azt állítják, hogy az oktatási rendszerben való egyenlő részvétel és az abban való eredményesség majd előbb-utóbb a nőknek fog kedvezni a munkaerőpiacon általában és a tudományos pályán különösen, hiszen meritokratikus társadalomban élünk. Ezzel szemben amellett érveltünk, hogy Magyarországon az elmúlt évtizedben visszalépés következett be a nemek egyenlőségének több területén is. A lista hosszú: láthatóak azok a közpolitikai változások, amelyek a nőket elsősorban anyaként határozzák meg, nem pedig független, jól képzett nőként. Rendszerszerű lépések történtek a női esélyegyenlőségi politikák és azok intézményi garanciáinak felszámolására, amelynek egyik utolsó lépése a társadalmi nemek mesterszak határozatban való megszüntetése volt.

Az MTA felől érkező, a tudós nők útjában álló akadályok azonosítását és megszüntetését, a diszkrimináció felszámolását és a nők helyzetbehozását támogató tudománypolitika, azaz a Nők a Kutatói Életpályán Elnöki Bizottság felállítása, nagyon fontos üzenetet hordoz a társadalom egésze felé (Bazsa 2019; Lamm-Nagy 2019). Ugyanakkor nem szabad, hogy túlzott reményeket támasszon bárkiben is a hosszú távú hatásainak automatikussá válásával kapcsolatban, mivel a nemek egyenlőségével kapcsolatos kérdések a status quo megkérdőjelezésével is járnak, így komoly érdekeket is sérthetnek.

\footnotetext{
Abstract: Although there was a strong expansion in the number of students and a feminization in higher education until 2012, this did not contribute to the decline of high gender segregation of disciplines or to the advancement of women in science. Moreover, many factors weaken the presence of women and hinder the reduction of gender segregation. This study, based on the most recent data (Felvi, CSO, MTA), presents patterns of horizontal and vertical segregation among women in the scientific field. Based on available international and domestic literature, the study seeks to find out why women's initial headcount in higher education is disappearing at higher levels of the scientific career. This suggests that many institutional and political barriers to gender equality in higher education are present. The outcome is a higher education policy and practice strengthening women's disadvantages, and the lack of alternative discourses about this topic. The paper intends to call attention to continuous wasting female talents in academia, which also reduces the innovation potential in Hungary.
}

Keywords: women in academia, education, gender equality, STEM, university enrollment 


\section{Irodalom}

Alpár D. - Barnaföldi G. G. - Dékány É. - Kubinyi E. - Máté Á. - Munkácsy B. - Neumann E. - Solymosi K. - Toldi G. (2019): Fiatal kutatók Magyarországon. Felmérés a 45 év alatti kutatók helyzetéről. Magyar Tudomány 180(7), 1064-1077. DOI: 10.1556/2065.180.2019.7.13.

Bazsa Gy. (2019): Nők az Akadémián: beszéljenek a számok! Magyar Tudomány, 180(7), 1078-1081. DOI: 10.1556/2065.180.2019.7.14.

Beilock, S. L. - Gunderson, E. A. - Ramirez, G. - Levine, S. C. (2010): Female teachers' math anxiety affects girls' math achievement. Proceedings at the National Academy of Sciences USA, 107(5): 1860-1863. doi: 10.1073/pnas.0910967107.

Britton, D. M. (2017): Beyond the Chilly Climate: The Salience of Gender in Women's Academic Careers. Gender \& Society, 31(1), 5-27. https://doi. org/10.1177/0891243216681494

Charles, M. - Thébaud, S. (eds.) (2018): Gender and STEM: Understanding Segregation in Science, Technology, Engineering and Mathematics MDPI Books https://doi. org/10.3390/books978-3-03897-148-1. Letöltés: 2018. április 15.

Csüllög K. - D. Molnár É. - Lannert J. (2014) A tanulók matematikai teljesítményét befolyásoló motívumok és stratégiák vizsgálata a 2003-as és 2012-es PISAmérésekben. In: Hatások és különbségek. Másodelemzések a hazai és nemzetközi tanulói képességmérések eredményei alapján, Budapest: Oktatási Hivatal

Declercq, K. - Varga J. (2018): Horizontális nemi szegregáció a felsőoktatásban - STEM jelentkezések. In: Fazekas Károly - Szabó-Morvai Ágnes (szerk.) Munkaerôpiaci Tükör 2017. Nók a munkaerőpiacon Budapest: MTA KRTK, 114- 121.

Eccles, J. S. - Roeser, R. W. (2013): Schools as Developmental Contexts During Adolescence. Journal of Research on Adolescence, 21(1), 225-241. https://doi. org/10.1111/j.1532-7795.2010.00725.x

Eccles, J. S. (1993): School and family effects on the ontogeny of children's interests, self-perceptions, and activity choice. In: J. Jacobs (ed.) Nebraska Symposium on Motivation, 1992: Developmental perspectives on motivation. Lincoln: University of Nebraska Press. 145-208.

Eurostat (2016): Online database. https://ec.europa.eu/eurostat/web/educationand-training/data/database

Fényes H. (2010): A nemi sajátosságok különbségének vizsgálata az oktatásban: A nök hátrányainak felszámolása? Debrecen: Debreceni Egyetemi Kiadó.

Füleki, K. - Groó, D. - Kleinheincz, F. - Paksi, V. (2018): EFFORTI - Deliverable 2.2 Country Note Hungary https://www.efforti.eu/publications/country-reports Letöltés: 2019. március 20.

Halász G. - Lannert J. (szerk.) (2000): Jelentés a magyar közoktatásról 2000, Budapest: OKI 
Herke B. - Kutrovátz K. - Paksi V. - Ivony É. (2019): Szakmai életutak a szociológia tudományterületén, Corvinus Szociológiai Doktori Iskola, kézirat MTA (2019): Tudományos fokozatok nemek szerint. 2019 április, Kézirat

Hermann Z. - Kopasz M. (2018): Educational policies and the gender gap in test scores. A cross-country analysis, BWP 2018/5

Hermann Z. (2018): Nemek szerinti tesztpontszám-különbségek nemzetközi összehasonlításban. In: Fazekas Károly - Szabó-Morvai Ágnes (szerk.) Munkaerőpiaci Tükör 2017. Nők a munkaeröpiacon Budapest: MTA KRTK, 97-102.

Hrubos 1. (1994): A férfiak és a nők iskolai végzettsége, szakképzettsége. In: Hadas Miklós (szerk.) Férfiuralom. Replika Könyvek 2. Bp., Replika Kör 155-175.

Infojegyzet (2014): Családpolitika. Infojegyzet 2014/9. 2014. április 18. http://www. parlament.hu/documents/10181/73472/Infojegyzet_2014_9_csaladpolitika. pdf/00dc5263-cd83-4fe0-9905-184f7dc57b53 Letöltés dátuma: 2019. április 3.

Kereszty O. (2007): A társadalmi nem (gender), mint a kutatás tárgya a pedagógiában, Educatio 4, 637-649.

Kormányhatározat (2010): A Kormány 1004/2010. (I. 21.) Kormányhatározata a Nők és Férfiak Társadalmi Egyenlőségét Elősegítő Nemzeti Stratégia - Irányok és Célok 2010-2021, Magyar Közlöny, 2010. évi 5. szám

Krizsán A. - Zentai V. (2006): Egyenlő bánásmód vagy gender mainstreaming? A nemek közötti egyenlőség politikája Magyarországon Replika 56-57 (2006. december) 181-201.

KSH (2018): Kutatás-fejlesztés 2017, KSH, Budapest

Lamm V. - Nagy B. (2019): 2019 ismét a „nők éve” az Akadémián. Törekvések a nők tudományos pályafutásának, Magyar Tudomány, 180(2019)11, 16 49-1665, DOI: 10.1556/2065.180.2019.11.6

Nagy B. (2014): Háttérben. Kísérlet egy szervezeti nemi rend feltárására, Budapest: L'Harmattan

OECD (2015): TheABC of Gender Equality in Education: Aptitude, Behaviour, Confidence, PISA, OECD Publishing. http://dx.doi.org/10.1787/9789264229945-en

OECD (2019): PISA in Focus. Why don't more girls choose stem careers? 2019/93, Paris: OECD, https://www.oecd-ilibrary.org/education/why-don-t-more-girlschoose-to-pursue-a-science-career_02bd2b68-en

Paksi V. (2014): Miért kevés a női hallgató a természet- és műszaki tudományi képzésekben? Nemzetközi kitekintés a „szivárgó vezeték”-metaforára. Replika 8586 108-130.

Paksi, V. - Nagy, B. - Király, G. (2016): The Timing of Motherhood While Earning a $\mathrm{PhD}$ in Engineering. International Journal of Doctoral Studies 11, 285-304 https:// doi.org/10.28945/3544 
Pető A. (2017): Anti-gender, azaz a társadalmi nemek fogalmát mint ellenségképet használó tudományos diskurzus megjelenése Magyarországon. In: Kovács Mónika (szerk.) Társadalmi nemek. Elméleti megközelítések és kutatási eredmények, Budapest, Eötvös Kiadó, 209-217.

Pető A. (2018): Nők a tudományban Magyar Tudomány 179(4), 550-565. DOI: 10.1556/2065.179.2018.4.9

Séllei N. (2015): Professzornők a debreceni egyetemen, Debreceni Szemle, 2015/3. 260-277.

Striebing, C. - Kalpazidou Schmidt, E. - Palmén, R. - Holzinger, F. - Nagy, B. (2020): Women Underrepresentation in R\&I: A Sector Program Assessment of the Contribution of Gender Equality Policies in Research and Innovation, Evaluation and Program Planning, 79 April, 101749, https://doi.org/10.1016/j. evalprogplan.2019.101749.

Szemerszki M. - Imre A. (2011): A felsőoktatásba jelentkezők és felvettek. In: Kocsis Mihály (szerk.) Felsőoktatás - Adatok és tendenciák. OFI Oktatáskutató és Fejlesztő Intézet, Kutatási, Kutatászervezési és Elemzési Központ Budapest. http://ofi. hu/tudastar/felsooktatas-110209 Letöltés ideje: 2019. április 1.

Thun É. (2006): A társadalmi nemek tudománya a neveléstudományban és a tanárképzés/pedagógusképzés pedagógiájában In: Pető A. (szerk.) A társadalmi nemek oktatása Magyarországon, Budapest: Ifjúsági, Családügyi, Szociális és Esélyegyenlőségi Minisztérium, Budapest, pp. 78-85.

Varga J. (2018): A női-férfi iskolázottsági különbségek alakulása. In: Fazekas Károly - Szabó-Morvai Ágnes (szerk.) Munkaerőpiaci Tükör 2017. Nők a munkaerôpiacon Budapest: MTA KRTK, 97-102.

Wang, M. T. - Degol, J. (2013): Motivational pathways to STEM career choices: Using expectancy-value perspective to understand individual and gender differences in STEM fields. Developmental Review, 33(4), 304-340. doi: 10.1016/j.dr.2013.08.001 